\title{
Supply chain management of coffee commodities
}

\author{
Andri Ikhwana ${ }^{1}$ \\ ${ }^{1}$ Sekolah Tinggi Teknologi Garut, Department of Industrial Engineering, Jl. Mayor Syamsu No. 1, Garut, 44151, Indonesia
}

\begin{abstract}
This study is aimed at describing the supply chain management of coffee commodity and the role of each of its elements. This study based on the ineffectiveness and inefficiency of coffee commodity business management which involves some elements that caused supply chain for the commodity has not been formed according to the expectation which in turn required a supply chain management able to fix the problem. The supply chain management is described qualitatively using supply chain basic model supported by integrated concepts of supply chain relationship, supply chain configuration, and supply chain coordination. The result of the study reveals that the supply chain management in coffee commodities includes suppliers, gatherers/manufacturers, exporters, and consumers. The distributors play the main role in determining product standards. The relationships between each of supply chain elements have been well established, utilized to distribute the products, and used as a feedback medium if there is a change in quality standards required in accordance with the needs of consumers. To ensure the sustainability of business activities in the supply chain, mutual commitment among the supply chain elements is required especially when it comes to determining the product quality standards and quantity.
\end{abstract}

\section{Introduction}

Coffee commodity-related businesses may open new businesses opportunities in branding, processing, and marketing. However, in practice, there are many challenges and difficulties especially in meeting the product quality standards in accordance with the needs of the consumers so that much better management is required in order for the sustainability of these coffeerelated businesses to benefit all stakeholders. It takes mutual agreements between suppliers, manufacturers, and costumes to improve the supply chain performance and networks [1]. These supply chain networks are in turn expected to be the main hub of sustainable business activity in an effort to meet the demands and needs of the customers [2] [3].

The coffee sector as one of the business activities involving supply chain requires good management to ensure its sustainability and good performance. It takes a good supply chain management, from the suppliers (farmers and gatherers), processors (gatherers and manufacturers), distributors (exporters and retailers), to the customers to be able to compete in the global market [4]. The supply chain management plays a role in ensuring the improvement of supply chain performance and quality by not only focusing of market improvement but also on the sustainability and improvement of the organizations involved in the supply chain [5]. Therefore, understanding the concept of supply chain excellence is the first stage to achieve the competitive advantage in the supply chain [6].

The role of supply chain management in increasing the optimality of a business and to preserve its continuity could be done through dynamic approach system by involving some aspect such as economy, social value, and environment [7], choosing business partner [8], cost efficiency through controlling material waste [9], product quality control [10], relationship among businessman [11], consumer-based innovation [12], and flexibility and responsiveness on current business competition [13]. Finally, in achieving Supply Chain Management excellences, environment control, social value achievement and corporate social responsibility need to be prioritized [14].

Some factors need to be taken into account to ensure the sustainability of supply chain excellences; such as: Supply Chain Configuration, which describes the entire supply chain and the arrangement of elements important to the business activities based on the involved elements [15], Supply Chain Relationship, which deals with what and how is the role of supply chain elements in determining the product quality standards, evaluating customer satisfaction, understanding customer expectations, and understanding the relationship of suppliers with existing consumers in the supply chain [16], Supply Chain Coordination, which is an important factor to ensure the sustainability of the supply chain [17], internal integration and information sharing [18] in an effort to deliver values desired by both parties (providers and consumers) [19].

\section{Methodology}

This research used a qualitative method. Data were collected through a Focus Group Discussion by involving coffee businessmen exist in Garut Regency and any

\footnotetext{
*Corresponding author: andri_ikhwana $@$,sttgarut.ac.id
} 
authority who has interest in coffee development as a commodity, supported by existing data from previous research and theoretical reviews. The scope of discussion is based on the concept of Supply Chain Management, which involves supply chain configuration, supply chain relationship, and supply chain coordination in coffee commodities [2]. Fig. 1 illustrates this scope.

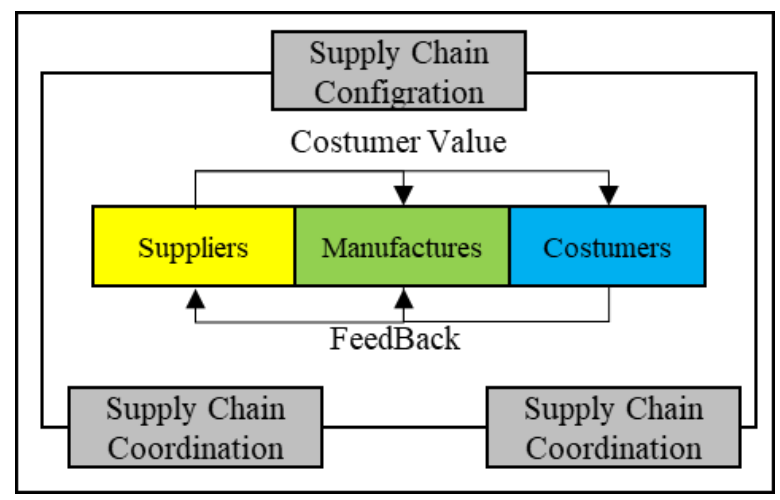

Fig. 1. Research Framework.

Based on research framework (fig. 1), research was done in two steps, which is:

- Recognizing coffee commodity business activity from start to finish, so every element involved within can be known. Also, at this stage, every obstruction which affects supply chain effectivity and efficiency can be described.

- Describe the role and function of each and every supply chain elements to see how it affect the success and continuity of coffee commodity business activity.

Through the two steps it is expected a suitable coffee commodity supply chain management can be formed.

\section{Result and discussion}

Coffee-based business in Garut regency is composed of various elements involved in it: suppliers (farmers and gatherers), coffee bean processors (gatherers and business people), distributors (exporters) and consumers. The business activity from upstream to downstream produce a variety of processed coffee products as described in Fig. 2.

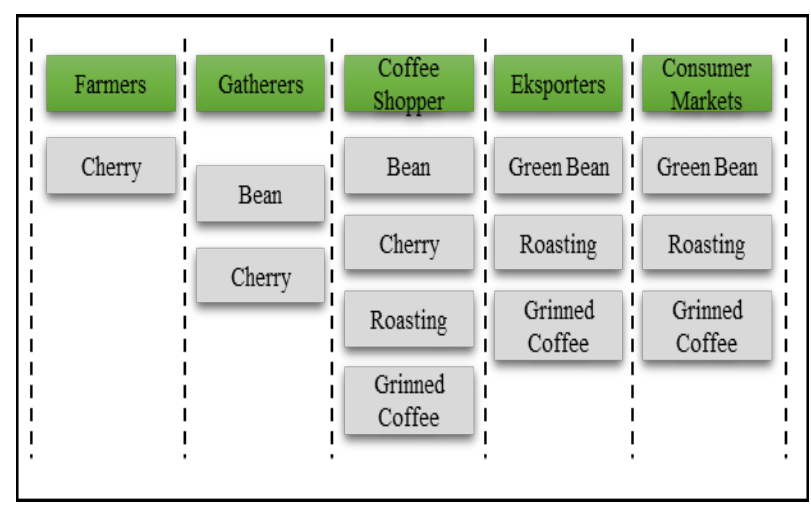

Fig. 2. Business Activity of Processed Coffee Products.
Based on the supply chain as described in Fig. 2, it can be said that the supply chain of coffee in Garut Regency consists of suppliers and distributors who play important roles in marketing processed coffee products.

Based on production process described, to further support coffee commodity business success and continuity, some distribution chains on some elements with the similar role can be omitted from the supply chain. Fig. 3 illustrates the supply chain of processed coffee products in Garut Regency.

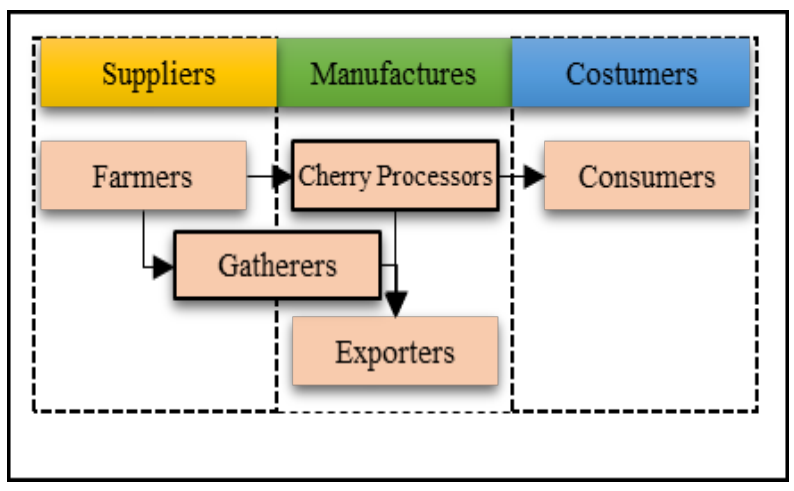

Fig. 3. Supply Chain of Processed Coffee Products.

Fig. 3 shows the supply chain management of processed coffee products in Garut Regency displays an integrated relationship between elements involved in the business activity. What follows is the description of each function of supply chain management elements that can ensure the sustainability and success of processed coffee products in question: 1) Supply Chain Configuration. The supply chain configuration in the processed coffee product sectors consists of farmers, manufacturers, distributors, and exporters. To ensure the sustainability of supply chain activities, the distributors are expected to be able to determine the product quality standards desired by consumers and to determine the types of products as well as their quantity; 2) Supply Chain Relationship. The relationship among supply chain elements in processed coffee sector plays an important role in ensuring the sustainability and success of supply chain business activities so that all elements involved in the supply chain are expected to understand their respective roles and functions. These roles and functions are described as follows: a) Farmers, Gatherers, and Manufacturers. The farmers sell their coffee to the gatherers and manufacturers in two forms: cherries and beans. Most farmers sell it in the form of cherries; b) Gatherers. The gatherers in Garut Regency sell the coffee in the forms of cherries and green bean. Most of them are cherries; c) Business People/Exporters Business people sell the coffee to the distributors in local markets such as Bandung and Jakarta and to the exporters who in turn sell it to global markets like Australia, Japan, and the U.S.; d) Other Parties. In addition to export commodity, coffee is also distributed to meet the domestic needs, especially cafés or personal demands in the form of ground coffee, and 3 an ) Supply Chain Coordination. the With regard to coordination performance in the supply chain, all elements, from upstream to downstream, involved in the 
coffee commodity business activities must be able to exchange information about their respective needs and provide feedback for each other.

From fig. 2 and 3 descriptions, some similar role and function between farmer and gatherer as coffee seed and green bean supplier so to achieve an effective supply chain, both actions can be merged by collaborating both processes. After coffee commodity supply chain management has been achieved with certainty. It is expected to help support and strengthen the continuity and success of coffee commodity supply chain which in turn can provide information on an accurate number of demand of the coffee product, productions estimates, production capacity stipulations, and standardize product quality. With supply chain management explained, a wellestablished supply chain management hopefully can form to be able to compete in the global market.

Therefore, the supply chain performance is influenced by two factors: the ability to involve elements to share information and to collaborate with each other [20] [21]. Supply chain coordination can be optimized by implementing knowledge portal about coffee-based business activities. Knowledge portal is the implementation of information technology that contains information relevant to a business process [22]. The coordination in processed coffee product supply chain should take into account policy and supports needed to improve technical capability of farmers and business people in the sector [23]. Therefore, the coordination function in the supply chain is required to meet the consumer needs and also to provide feedback from the consumers to the providers in the supply chain.

\section{Conclusions}

In order to support the success and continuity of business activity on the coffee commodity supply chain, merging of some elements with similar role such as merging between farmer and gatherer who both are a coffee supplier. Based on field research results, continuity and success of coffee commodity business activity which involved every element within its supply chain, the relationship of every element (SCM relationship), also the role and function of each and every elements in SCM (SCM coordination) has to be fully recognized. If it can be fully recognized, information derived from it such as: standard production capacity on every supply chain which had to be fulfiled annually, its product quality standards, and also the feedback of each and every supply chain element to further support the success and continuity of coffee commodity business activity especially in facing global market competition.

Thanks to Sekolah Tinggi Teknologi Garut which inspiringly support the publication of this article.

\section{References}

1. L. L and P. Gibson, Implementing Supply Chain Quality Management in Subcontracting System for Construction, Quality journal of System and
Management Science, vol. 1, no. 1, pp. 45-58, (2011)

2. L. David, Fundamental of Supply Chain Management, Ventus Publishing ApS: Ventus Publishing ApS; ISBN 978-87-7681-798-5, (2011)

3. R. A. Nggili and R. K. Rudolf, "Supply Chain Management Batu Mulia Kahas Nusantara di Kotamadya Salatiga, J Manajemen Teori dan Terapan, vol. Tahun 10 No. 2, (2017)

4. A. Sharma, G. Dixit and A. Agarwal, Quality Management in Supply Chains: The Literatur Review, Int. J for Quality Research, Vol. 6, no. N0. 3, (2011)

5. A. Agus, Supply Chain Management; Production Quality and Business Performance, 2001 International Conference on Sociality and Economics Development IPEDR, Vol. 10 (2011. )

6. B. Huo, B. F. Barbara and Z. Xiande, Supply Chain Power Configurations and their Relationship with Performance, J. of Supply Chain Management, vol. Vol. 53, no. No. 2, (2017)

7. R. Jaya, Machfud, S. Raharja and Marimin, Predicition of Sustainable Supply Chain Management for Gayo Coffee Using System Dyanamic Approach, J of Theoretical and Applied Information Technology, vol. 70, no. 2, pp. 372380, (2014)

8. X. T. Nguyen, G.-H. Lin and N. B. T. Nguyen, Application of AHP Method in Analysing and Selecting the Right Supplier Case of Instant Coffee Supplier for Hanoi Big C Supermarket, in International Conference on Computational Intelligence and Applications, (2016)

9. V. H. Machado, A. P. Barroso and V. C. Machado, Coffee Waste Management, A Case Study, in Proceeding of the 2011 IEEE IEEM, (2011)

10. H. L. YIN and Y. M. WANG, An Effective Method for Vegetable Spply Chain Quality Management in Proceeding of the 36th Chinese Control Conference, (2017)

11. A. Susanty, A. Bakhtiar, R. Purwaningsih and D. F. Dewanti, Performance Measurement of the Relationship Between Farmers-Cooperatives Industrial Processing Milk in a Dairy Supply Chain: A Balanced Supply Chain Management Scorecard Approach, in Proceeding of the 2017 IEEE IEEM, (2017)

12. S. E. Sampson and M. Spring, Customer Roles in Service Supply Chain and Opportunities for Inovation, J of Supply Chain Management, vol. 48, no. 4, pp. 30-50, (2017)

13. M. J. Markley and L. Davis, Exploring Future Competitive Advantage Through Sustainable Supply Chain, Int $\mathbf{J}$ of Physical Distribution \& Logistic Management, vol. 37, pp. 763-774, (2007)

14. G. N. T. Nguyen and T. Sarker, Sustainable coffee supply chain management: a case study in Buon $\mathrm{Me}$ 
Thuot City, Daklak, Vietnam, Int. J of Coorporate Social Responsibility, pp. 1-17, (2018)

15. D. M. Masi, D. Steven and J. Godsell, Supply Chain Configurations in the Circular Economy: A Systematic Literature Review, J Sustainability, vol. (2017)

16. M. Wullur and Wardaya, Moderating Role of Supply Chain Management Practices and eBusiness Technology in Manufacturing Companies, $J$ Manajemen Transportasi \& Logistik, Vol. 02, no. No. 02, (2015)

17. S. G. J and R. Kant, Supply Chain Practices, Int J of Productivity and Performance Management, vol. 64, no. 05 , pp. 657-685, (2015)

18. I. A. Mufaqih, N. Indarti, W. S. Ciptono and A. Kartikasari, Pengaruh Integrasi, Berbagi Informasi, dan Penundaan pada Kinerja Rantai Pasokan : Studi pada Usaha Kecil Menengah Batik di Indonesia, $J$ Siasat Bisnis, vol. 21, no. 1, (2017)

19. C. Martin, Logistic and Supply Management Fourth Edition, (Prentice Hall, London, 2011)

20. J. R. Montoya-Torres and A. Ortiz-Vargas D., Collaboration and information sharing in dyadic supply chains: A literature review over the period 2000-2012, Estudios Gerenciales, 30, pp. 343-354, (2014)

21. I.-L. Wu, C.-H. Chuang and C.-H. Hsu, "Information sharing and collaborative behaviors in enabling supply chain performance: A social exchange perspective, Int J Production Economics, vol. 148, pp. 122-132, (2014)

22. A. Pamoragung, K. Suryadi and M. A. Ramdhani, "Enhancing the Implementation of e-Government in Indonesia Through the High-Quality of Virtual Community and Knowledge Portal," in 6th European Conference on e-Government, Marburg, (2006)

23. A. Ikhwana, Analisis Dan Strategi Penambahan Nilai Jual Komoditas Kopi Melalui Penataan Rantai Nilai Komoditas Kopi, J Kalibrasi, vol. 15, pp. 1-8, (2017) 